\title{
Формирование светоизлучающих и фотодетектирующих в ИК-области тонкослойных структур Ge:Sb/Ge методами ионной имплантации, вакуумного осаждения и импульсного отжига
}

\author{
Р.И. Баталов ${ }^{1)}$, Р.М. Баязитов ${ }^{1)}$, И.А. Файзрахманов ${ }^{1)}$, В.А. Шустов ${ }^{1)}$, А.В. Новиков ${ }^{2)}$, \\ П.А. Бушуйкин ${ }^{2)}$, Н.А. Байдакова ${ }^{2)}$, М.Н. Дроздов ${ }^{2)}$ \\ ${ }^{1)}$ Казанский физико-технический институт, \\ Федеральный исследовательский центр «Казанский научный центр РАН», \\ Казань, 420029, ул. Сибирский тракт, 10/7 \\ ${ }^{2)}$ Институт физики микроструктур, Федеральный исследовательский иентр «Институт \\ прикладной физики РАН», Нижний Новгород, 603950, ГСП-105 \\ тел:+7 (843) 231-9102, факс:+7 (843) 272-5075, эл.nочта: batalov@kfti.knc.ru
}

DOI 10.34077/RCSP2019-163

Слои германия $(\mathrm{Ge})$, легированные донорной примесью $(\mathrm{P}, \mathrm{As}, \mathrm{Sb})$ с концентрацией $N=10^{19}-10^{20}$ $\mathrm{cm}^{-3}$, являются перспективным материалом для микроэлектроники, фотоники и сенсорной техники при создании быстродействующих полевых транзисторов, инфракрасных светодиодов, лазеров и фотоприемников, а также сенсоров различных химических веществ.

Актуальной проблемой при формировании тонкопленочных гетероструктур на основе таких слоев, напр. Ge:Sb, является низкий уровень растворимости донорной примеси в $\mathrm{Ge}$ (или степень электрической активации), который в равновесных условиях роста, как правило, не превышает $10^{19}$ $\mathrm{cm}^{-3}$. Использование неравновесных методов получения сильно легированных слоев, таких как ионное со-распыление, ионная имплантация и импульсный наносекундный отжиг, может позволить преодолеть данную проблему.

$\mathrm{B}$ данной работе сильно легированные слои $\mathrm{Ge}: \mathrm{Sb}$ толщиной 0.1-0.3 мкм были получены двумя методами: (1) ионным распылением в вакууме композитной мишени $<\mathrm{Sb} / \mathrm{Ge}>$ с осаждением пленки на подложку p-Ge, (2) имплантацией ионов $\mathrm{Sb}^{+}$в монокристалл $\mathrm{p}-\mathrm{Ge}$. Получаемые слои имели аморфную структуру, и для их кристаллизации и электрической активации донорной примеси $\mathrm{Sb}$ применялась импульсная (наносекундная) ионная обработка (ИИО) пучком ионов углерода и водорода $\left(\mathrm{C}^{+}, \mathrm{H}^{+}\right)$, а также импульсный лазерный отжиг (ИЛО) на длине волны 1.06 мкм импульсами микросекундной или наносекундной длительности. Во всех случаях отжиг проходил в жидкофазном режиме. Проводилось компьютерное моделирование импульсного нагрева аморфных слоев $\mathrm{Ge}$ и его данные сопоставлялись с экспериментом. С использованием широкого набора экспериментальных методов изучались структурные, оптические и электрические свойства облученных слоев $\mathrm{Ge}: \mathrm{Sb}$.

Проведенное моделирование позволило оценить глубину, длительность расплава и температуру на поверхности $\mathrm{Ge}$ в процессе ИИО и ИЛО при различных режимах воздействий. Методом ВИМС установлена значительно более глубокая диффузия $\mathrm{Sb}$ в $\mathrm{Ge}$ при ИИО (до 1.5 мкм), чем при ИЛО, что связано с большей глубиной расплава. Определены режимы импульсного отжига, при которых на подложке p-Ge формировались эпитаксиальные слои n-Ge:Sb. Из измерений по Холлу, плазменному отражению и рентгеновской дифракции на вакуумно-осажденных и имплантированных слоях $\mathrm{Ge}: \mathrm{Sb}$ получены высокие значения концентрации электронов проводимости вплоть до $5 \times 10^{20} \mathrm{~cm}^{-3}$. Измерения фотолюминесценции при 300 К показали возрастание вклада от прямого перехода при 0.77 эB (1610 нм) в слоях $\mathrm{Ge}: \mathrm{Sb}$ после ИИО. Измерения фотопроводимости на диодной структуре $\mathrm{n}$ $\mathrm{Ge}: \mathrm{Sb} / \mathrm{p}-\mathrm{Ge}$ показали более интенсивный и расширенный до 2 мкм фотоотклик в сравнении с типовым Ge фотодиодом. 